\title{
Simulation Study of Building Integrated Solar Liquid PV-T Collectors
}

\author{
Tomas Matuska \\ Faculty of Mechanical Engineering, Czech Technical University in Prague, Technicka 4, 16607 Prague, Czech Republic \\ Correspondence should be addressed to Tomas Matuska, tomas.matuska@fs.cvut.cz \\ Received 7 April 2012; Accepted 26 May 2012 \\ Academic Editor: T. T. Chow \\ Copyright () 2012 Tomas Matuska. This is an open access article distributed under the Creative Commons Attribution License, \\ which permits unrestricted use, distribution, and reproduction in any medium, provided the original work is properly cited. \\ Influence of building integration of polycrystalline PV modules on their performance and potential for use of active liquid cooling \\ by use of BIPV-T collectors has been investigated by simulation analysis with a detailed model. Integration of PV modules into \\ building envelope could reduce the annual production of electricity by a rate above $5 \%$ and negatively influence lifetime due to \\ thermal stresses induced by high operation temperatures above $100^{\circ} \mathrm{C}$ in the case of warm climate and above $90^{\circ} \mathrm{C}$ in moderate \\ climate. Two configurations of unglazed PV-T collectors (low-tech, high-tech) and their ability to eliminate overheating of BIPV \\ module have been discussed. Simulation study on combined heat and electricity production from given BIPV-T collectors has \\ been presented for three typical applications $\left(5^{\circ} \mathrm{C}\right.$ : primary circuits of heat pumps; $15^{\circ} \mathrm{C}$ : cold water preheating; $25^{\circ} \mathrm{C}$ : pool water \\ preheating). Thermal output of unglazed BIPV-T collectors is up to 10 times higher than electricity. Electricity production could \\ be up to $25 \%$ higher than BIPV (without cooling) for warm climate and up to $15 \%$ in moderate climate.
}

\section{Introduction}

Utilization of solar energy being a scarce energy source needs a large area of south-facing collecting surfaces. Rational use of building envelopes for the collection of solar energy and its conversion to required energy carrier results into integration of active solar devices into the building envelope structure and leads to multifunctional or hybrid solar collector configurations combining several purposes (heat and electricity generation, daylighting, and air-liquid) in a single unit [1]. The integration of solar collectors into building envelope instead of separate installation represents a transition from the concept of envelope considered as an energy loss to envelope being an energy source-energy active envelopewhich actually means a way to solar active buildings. As photovoltaic modules are getting more and more common in sustainable buildings in order to compensate the electricity consumption by electricity production on site, the combination of photovoltaic and solar thermal technology in hybrid PV-T collectors could represent a step further with combined heat and power production (solar cogeneration).

Standard commercial PV modules cannot convert more than $15 \%$ of incident solar radiation to electricity, the rest of energy is converted to waste heat which increases temperature of PV cell. The rise of PV cell temperature affects negatively the efficiency of photovoltaic solar/electricity conversion. Aesthetically preferred building envelope integrated PV (BIPV) installations could show significantly higher operation temperatures than separate standalone PV modules due to limited natural cooling by wind. Introduction of active cooling of BIPV modules results in hybrid photovoltaic-thermal collectors (PV-T collectors) which can provide low-temperature heat and electricity, while heat production is usually several times higher than electricity.

There are generally three reasons to use PV-T collectors instead of PV collectors in building envelope integrated applications:

(i) overheating protection-reduction and elimination of excessive thermal load of PV cells lamination (EVA foil) and protection from accelerated degradation;

(ii) increase of electricity production by keeping the PV cell at considerably lower operation temperatures during a whole year;

(iii) higher specific energy gain from $1 \mathrm{~m}^{2}$ of building envelope compared to separate installation of PV 
and PT collectors, if low potential heat is usable in technical system of the building.

Hybrid PV-T collectors can be generally realised in several principal alternatives: glazed or unglazed, flatplate or concentrating and with different heat removal liquids (air, liquid). Review of recent extensive research on different construction types of PV-T technology can be found in [25]. Hybrid PV-T air collectors with natural cooling do not allow an effective removal of the heat from PV cell. On the other hand, forced air circulation consumes auxiliary electricity which can generally negate the higher electricity gain achieved by cooling if not properly designed. PV-T air systems have also a limited potential for building integration due to large air duct systems and low usability of ambient warm air for cooling in summer season [6].

Contrary to PV modules cooled by air, PV-T liquid collector concept seems to be more suitable for BIPV applications if combined with efficient use of low temperature heat, for example, for cold water preheating, swimming pool heating circuits, or primary circuits of heat pumps. Several studies have been led on combination of unglazed PV-T collectors with heat pumps $[7,8]$ or floor heating [9]. Unglazed PV-T liquid collectors are suitable to applications with priority of electricity generation and waste heat removed from cells is a byproduct at low temperature level with worse usability than in standard solar thermal collectors. While glazed PV-T collectors allow higher operation temperature levels and better usability of generated heat, on the other side they face, lower production of valuable electricity, and the problems with too high stagnation temperatures for PV cells (even above $120^{\circ} \mathrm{C}$ ) still remain unsolved [10]. Unglazed solar PV-T collectors represent a robust and simple construction. They have been already introduced into the market in a number of products recently, also in concepts ready for building integration. However, price of PV-T collectors especially those with high quality of heat removal (high-tech) is relatively high, often more than double or triple when compared with PV modules alone. Therefore, there are attempts to reduce cost-benefit ratio through the development of low-tech configurations based on standard PV modules but with generally lower thermal performance due to heat removal restrictions resulting from simplifications of design [11]. Several studies are available on building integrated PV-T solar collectors [12-14] used as multifunctional components for built environment.

This work is focused on building integrated solar liquid PV-T collectors and several analyses are presented. First, the operation conditions of both building integrated PV modules and separately installed PV modules are simulated in two different European climates (warm, moderate). Performance figures of both installations are compared and reasons for BIPV cooling are revealed. Further, thermal performance of two different configurations of unglazed PV$\mathrm{T}$ collectors representing high-tech and low-tech alternatives is analysed in detail both for building envelope integrated and separate installations. Heat transfer rate and efficiency of PV cell cooling expressed by efficiency factor $F^{\prime}$ and its influence on operation temperature of PV cell are discussed.
Finally, performance figures of combined heat and electricity generation by unglazed BIPV-T collectors (high-tech, lowtech) are presented for three temperature levels representing the low temperature applications.

\section{Modelling of (BI)PV and (BI)PV-T Collectors}

There is a number of mathematical models developed for solar liquid PV-T collectors [15-17]. A detailed mathematical model of unglazed solar flat-plate hybrid PV-T liquid collector (PVT-NEZ) has been developed recently [18] and validated with experimental investigations [19]. Model is based on principle theory for energy balance of solar thermal collectors [20] expanded for photovoltaic conversion [21]. Calculation approach of PVT-NEZ model uses external energy balance of PV-T absorber (heat transfer from PV$\mathrm{T}$ absorber surface to ambient) and internal energy balance of PV-T absorber (electric yield, heat transfer from PV$\mathrm{T}$ absorber surface to liquid), see Figure 1. Both balances are solved in iteration loops to find temperature of PV-T absorber (PV cell) and relevant heat transfer coefficients. Both external and internal energy balances of absorber are mutually dependent and superior loop transfers the results of external balance to internal balance (collector heat loss) and results of internal balance to external balance (mean absorber temperature). Detailed description of mathematical model can be found in literature [18].

Input parameters of the model are thermal, optical, electrical, and geometrical properties of individual parts of PV-T collector (e.g., PV reference electric efficiency, temperature coefficient; material and geometry for heat exchanger, thermal insulation layer if applied), climate conditions (solar irradiance, ambient temperature and humidity, wind velocity, and sky temperature), and operation conditions (temperature of liquid entering collector, mass flow rate). Main output parameters of the model are usable electric and thermal power, output temperature of liquid, and temperature of absorber surface (PV cell). Building envelope integrated installations are modelled with added adjacent envelope insulation layer of given heat resistance at the back side of PV or PV-T collector with constant temperature behind considered (as interior temperature), see Figure 1(b).

Mathematical model PVT-NEZ of unglazed solar flatplate PV-T liquid collector allows to analyze and to optimize the collector construction based on detailed design parameters and operation/climate conditions. Moreover, mathematical model could be used as a universal tool; the electric and thermal output and efficiency can be evaluated for various PV-T collector configurations as well as only thermal output for strictly thermal unglazed collector (efficiency $\eta_{\mathrm{el}, r}=0$ ) or strictly electric output of PV module (liquid mass flow set to $0 \mathrm{~kg} / \mathrm{s}$ ) with temperature and solar irradiance effects on its performance. The model could be used for theoretical analyses or as a base for validation of real product models from experimental data.

To simulate the annual energy output of solar PV modules and PV-T collectors, simulation tool coupling the detailed mathematical model PVT-NEZ and hourly climate 


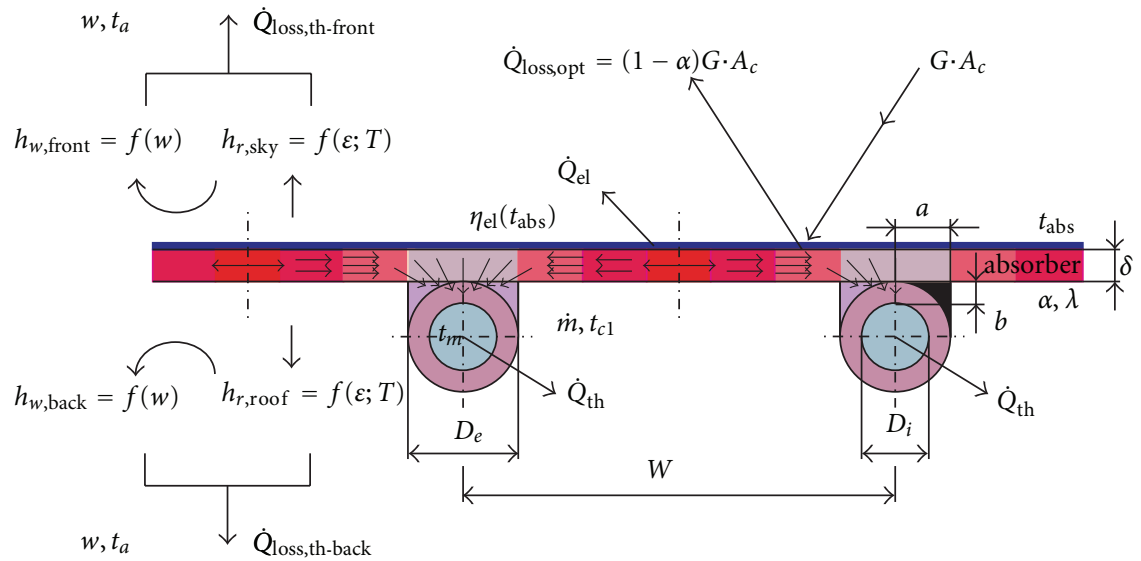

(a)

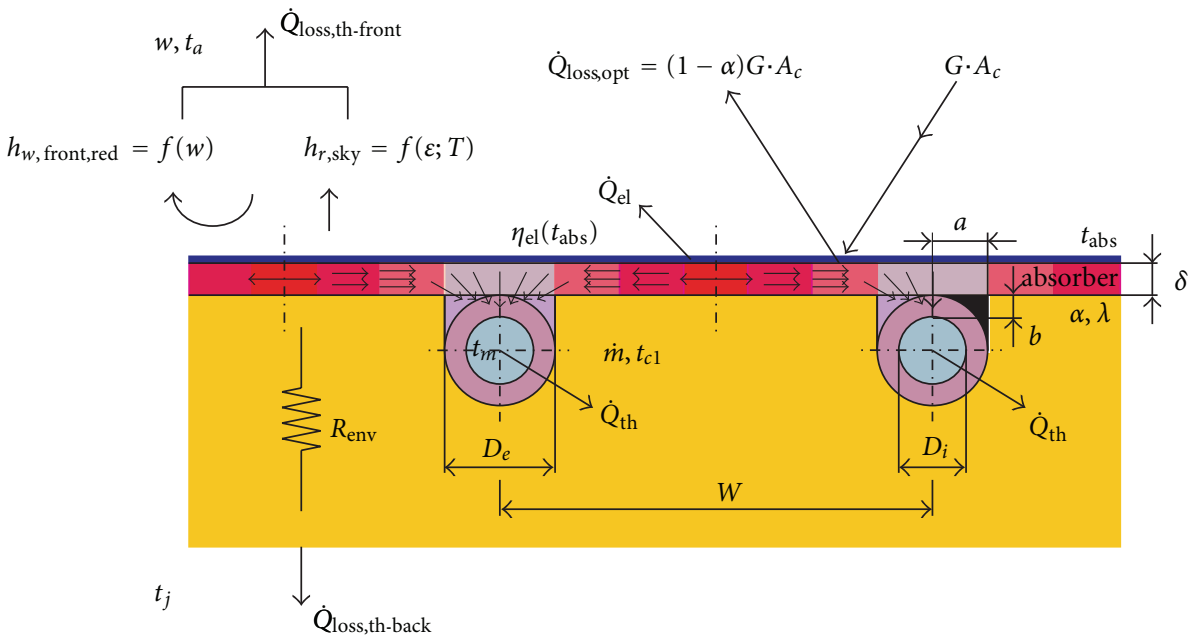

(b)

Figure 1: Scheme of unglazed PVT-NEZ model (separate and building envelope integrated installation).

data processor which supplies boundary conditions for the model in each simulation step has been developed. Incidence-angle-dependent optical properties of PV-T collectors (IAM characteristics) have been considered. Performance of unglazed solar collectors is strongly influenced by wind and sky radiation conditions due to direct influence on $U$-value and indirectly also on collector efficiency factor $F^{\prime}$. Detailed modelling of these relationships with iteration external/internal balance loop in PVT-NEZ model for each calculation time step has provided more precise results for annual energy outputs than simplified models related to reduced number of influence factors.

Hourly data processor uses climate databases from Meteonorm [22] with meteorological elements: solar irradiation, ambient temperature, wind velocity, and relative humidity. Additional parameters are operation conditions given by mass flow and temperature of cooling liquid entering the PV-T collector. These parameters were maintained constant throughout the simulations. Positive hourly outputs have been summed up, negative set to zero. When negative thermal output was determined, the electric output was taken without cooling effect to take into account the real operation (system pump is off).

\section{Overheating of BIPV Collectors}

General experience from applications of building integrated of PV modules is the operation at elevated temperatures due to limited heat transfer from PV to ambient. In the extreme climate conditions (clear hot day with no wind), the operation temperatures can overcome the safe limit value $80^{\circ} \mathrm{C}$. Figure 2 shows the electric efficiency of polycrystalline PV module in standalone and building integrated application at different solar irradiance and wind velocity levels for ambient temperature $25^{\circ} \mathrm{C}$. Standard polycrystalline module has been considered with efficiency $14.2 \%$ (at STC) and temperature coefficient $0.45 \% / \mathrm{K}$. Thermal resistance of adjacent envelope is $6 \mathrm{~m}^{2} \mathrm{~K} / \mathrm{W}$. It is apparent that the integration of $\mathrm{PV}$ module into building envelope brings a significant thermal stress for PV cells, temperatures of PV cells excess $80^{\circ} \mathrm{C}$ at no wind conditions and can induce the degradation or 


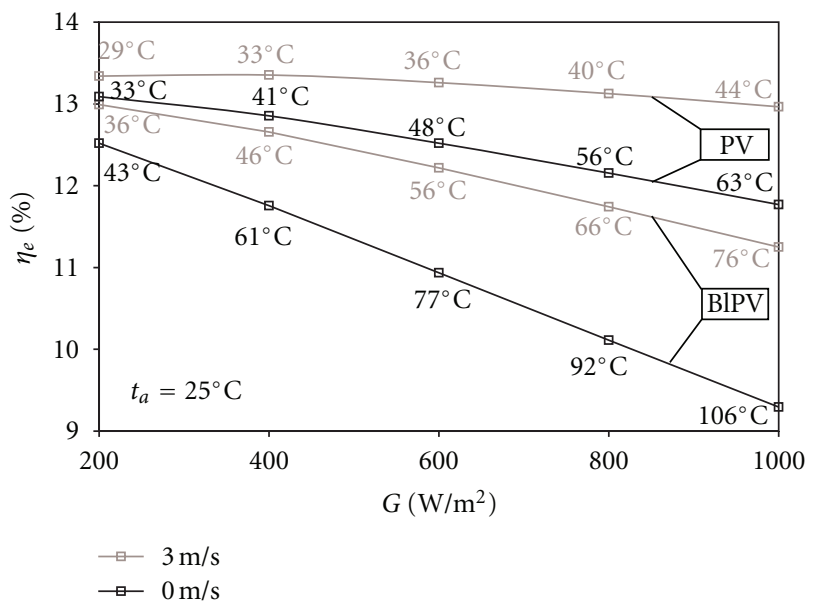

Figure 2: Efficiency and temperature of PV modules (separate and building envelope integrated installation).

even destruction of PV cells at such an extreme climate conditions.

Figure 2 shows also a characteristic decrease of PV module efficiency with higher level of irradiance due to direct influence on PV temperature rise at a given wind velocity. Generally, polycrystalline PV module efficiency rises with solar irradiance if temperature of PV cell is kept low. This could be seen for high wind velocity $(3 \mathrm{~m} / \mathrm{s})$ and separate installation of PV module. Increase of efficiency due to higher solar irradiance above $400 \mathrm{~W} / \mathrm{m}^{2}$ has been compensated by the decrease due to PV cell temperature rise. For other curves, it is not apparent due to prevailing temperature effect.

Presented examples do not provide information on annual PV operation figures in a real climate. Simulation analysis of PV module operation in separate (PV) and building envelope integrated (BIPV) installation has been performed for two different climates (warm-Athens/GR, moderate-Prague/CZ). Two alternatives of the collector tilt have been considered: optimum tilt for a given climate (Athens $30^{\circ}$, Prague $35^{\circ}$ ) and facade $\left(90^{\circ}\right)$. Orientation of collectors is south for all cases. Figures 3 and 4 show the histograms of PV module operation temperature. Impact of building integration and associated overheating of PV module on its electric performance in real operation conditions is given by the frequency of occurrence of high irradiation level and reduced wind cooling combination. The histograms show the increase of extreme temperatures frequency (above $80^{\circ} \mathrm{C}$ ) especially for roof installations in warm climate (Athens). Facade BIPV application is not concerned by excessive temperatures for both considered climates.

Separate roof and facade installations of PV modules do not bring extreme temperatures and stress for PV cells. Operation temperatures of PV modules could be maintained bellow $60^{\circ} \mathrm{C}$ in both climates. PV module integration into the roof increases the frequency of high-temperature occurrence above $60^{\circ} \mathrm{C}$. Especially in warm climate, the frequency of

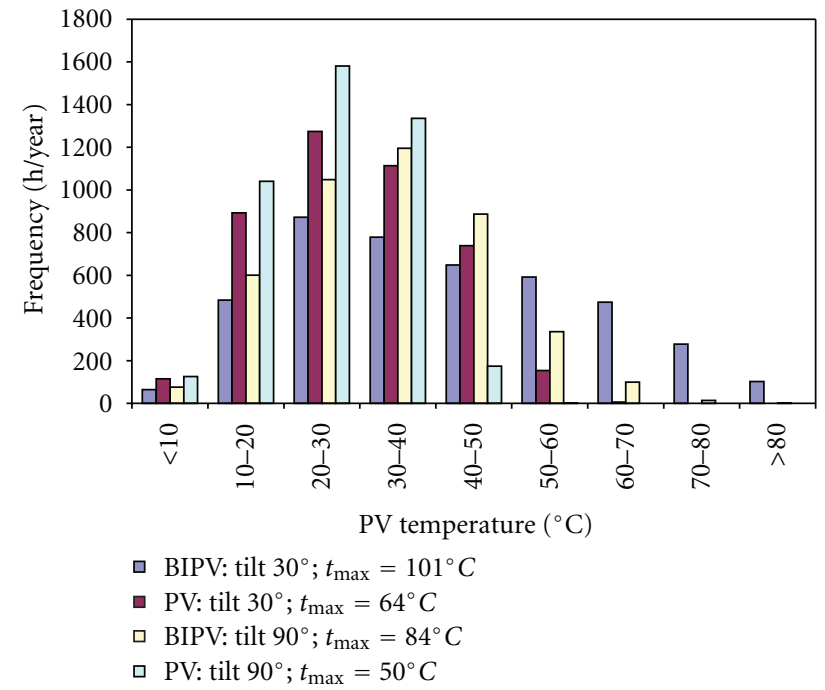

FIGURE 3: Operation temperature of PV module in separate installation (PV) and building envelope integrated installation (BIPV) for warm Athens (Greece) climate.

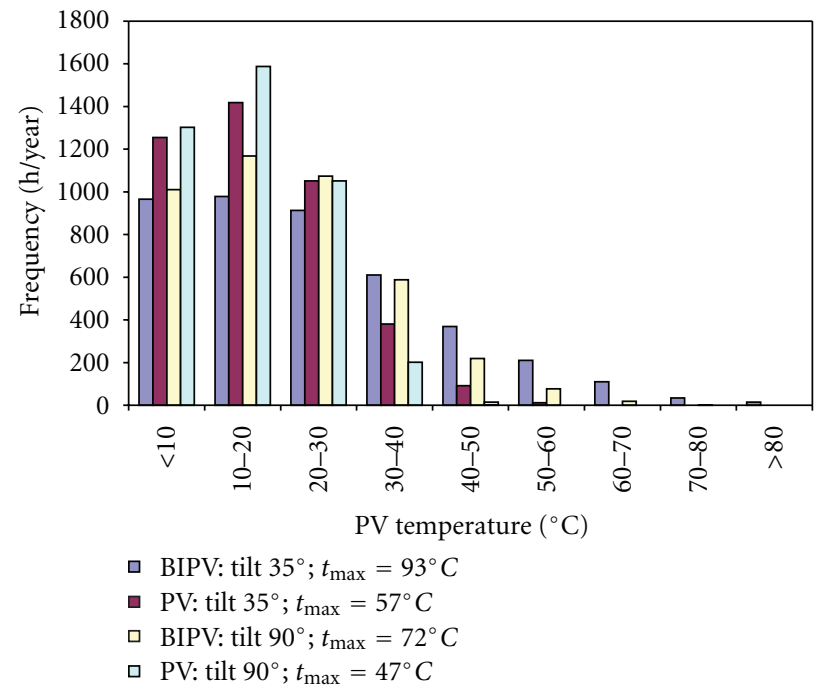

FIGURE 4: Operation temperature of PV module in separate installation (PV) and building envelope integrated installation (BIPV) for moderate Prague (Czech Republic) climate.

temperatures above $80^{\circ} \mathrm{C}$ becomes significant. Moderate climate shows low frequency of extreme temperatures; however maximum temperature $93^{\circ} \mathrm{C}$ indicates possible problems (tension in PV cell, cracking, delamination of foils, etc.). PV module integration into the facade does not show real problems to safe operation of PV for considered climates.

Shift of operation temperature to higher levels due to integration brings also the decrease of annual electric performance of building envelope integrated modules. Table 1 compares the annual electricity production by a given $\mathrm{PV}$ module per $\mathrm{m}^{2}$ for investigated installation (roof BIPV and PV, facade BIPV and PV) and indicates the loss of the electricity yield by building integration. 
TABLE 1: Yield reduction due to envelope integration of PV module.

\begin{tabular}{|c|c|c|c|c|}
\hline \multirow{2}{*}{ Climate } & \multicolumn{2}{|c|}{ Roof } & \multicolumn{2}{|c|}{ Facade } \\
\hline & BIPV & PV & BIPV & PV \\
\hline \multirow{2}{*}{ Athens } & $192 \mathrm{kWh} /\left(\mathrm{m}^{2} \cdot \mathrm{a}\right)$ & $210 \mathrm{kWh} /\left(\mathrm{m}^{2} \cdot \mathrm{a}\right)$ & $121 \mathrm{kWh} /\left(\mathrm{m}^{2} \cdot \mathrm{a}\right)$ & $128 \mathrm{kWh} /\left(\mathrm{m}^{2} \cdot \mathrm{a}\right)$ \\
\hline & & & & \\
\hline \multirow{2}{*}{ Prague } & $129 \mathrm{kWh} /\left(\mathrm{m}^{2} \cdot \mathrm{a}\right)$ & $138 \mathrm{kWh} /\left(\mathrm{m}^{2} \cdot \mathrm{a}\right)$ & $89 \mathrm{kWh} /\left(\mathrm{m}^{2} \cdot \mathrm{a}\right)$ & $93 \mathrm{kWh} /\left(\mathrm{m}^{2} \cdot \mathrm{a}\right)$ \\
\hline & \multicolumn{2}{|c|}{$-7 \%$} & \multicolumn{2}{|c|}{$-5 \%$} \\
\hline
\end{tabular}

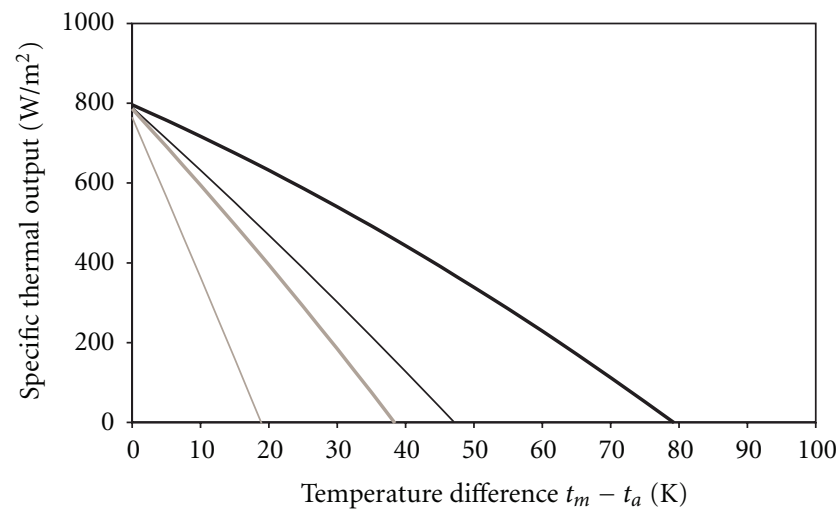

\footnotetext{
- High-tech, building integrated, $w=0 \mathrm{~m} / \mathrm{s}$

- High-tech, building integrated, $w=3 \mathrm{~m} / \mathrm{s}$

- High-tech, separate, $w=0 \mathrm{~m} / \mathrm{s}$

High-tech, separate, $w=3 \mathrm{~m} / \mathrm{s}$
}

FIgURE 5: Thermal output characteristics for high-tech PV-T collector at different configurations and conditions.

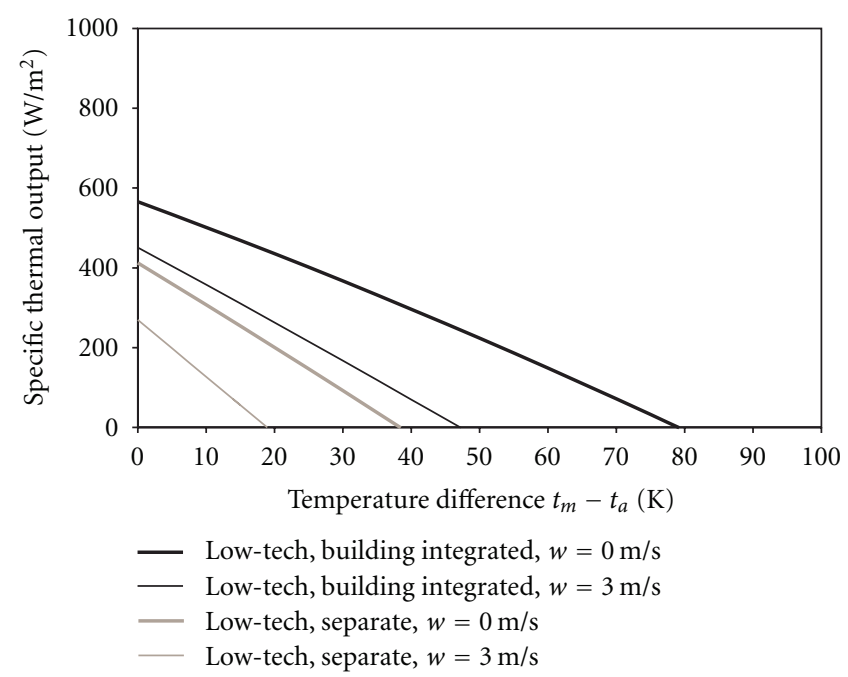

Figure 6: Thermal output characteristics for low-tech PV-T collector at different configurations and conditions.

Loss in energy production of PV module by building integration for the considered climates is quite similar. BIPV in warm climate with higher irradiance levels lose $9 \%$ in roof installations and $6 \%$ in facade installations; relevant figures for moderate climate are $7 \%$ and $5 \%$ of loss.

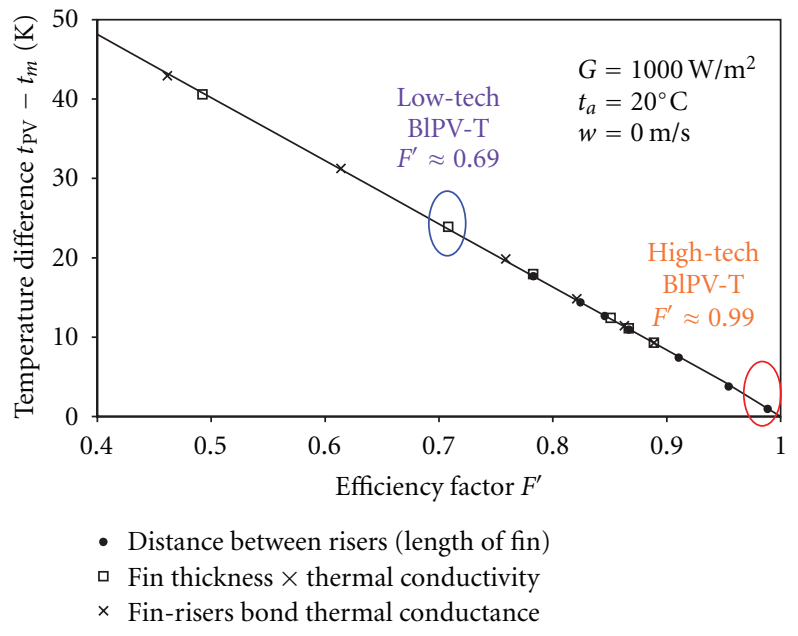

Figure 7: Relation between PV-liquid temperature difference and efficiency factor for BIPV-T collectors.

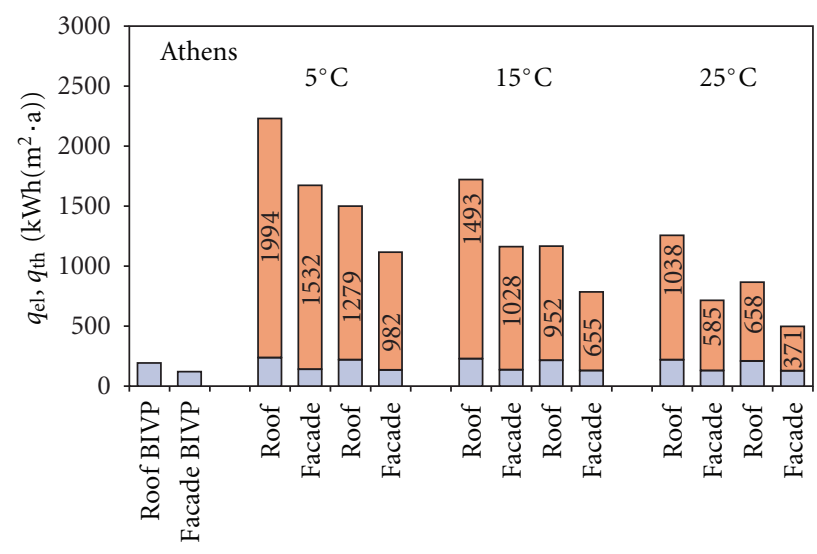

High-tech Low-tech

High-tech Low-tech High-tech Low-tech

$\square$ Electricity production

$\checkmark$ Heat production

FIgURE 8: Energy production from roof and facade BIPV-T collectors in warm climate (Athens).

The need for protection of PV modules against extreme operation temperatures as well as the need to keep the electricity production at sufficient level results in efforts to cool the PV modules and to develop the different BIPV-T collector configurations. 


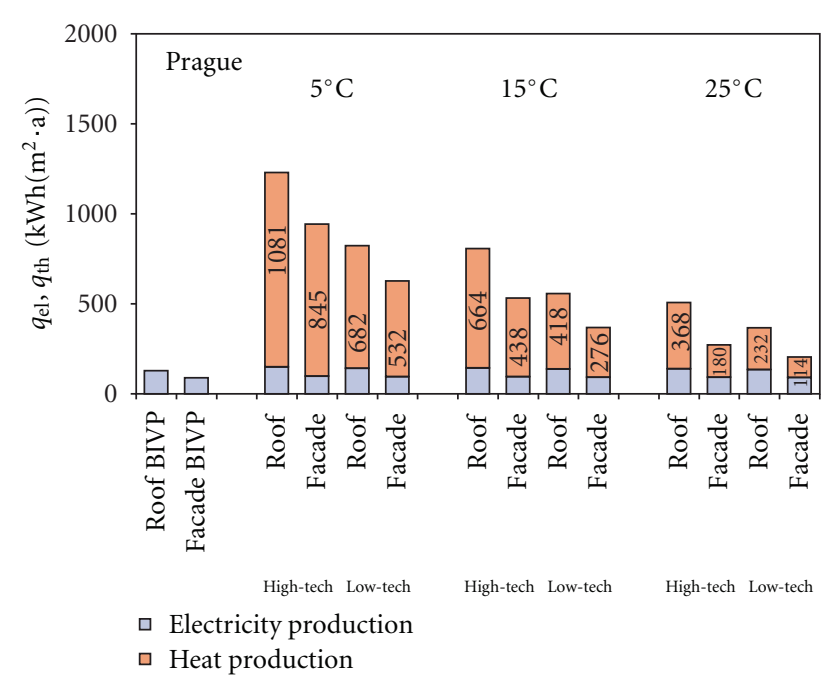

Figure 9: Energy production from roof and facade BIPV-T collectors in moderate climate (Prague).

\section{Thermal Performance of BIPV-T Collectors}

Generally, electrical and thermal outputs of PV-T collectors are mutually dependent. Higher electricity output through higher photovoltaic conversion efficiency results in lower thermal output of the collector, that is, lower level of waste heat removed from PV module. However, considering a given photovoltaic conversion efficiency of PV cell, the thermal performance of PV-T collector can be regarded as an indicator of overall quality defined by ability to cool down the PV module. Efficiency of PV module cooling depends on heat transfer from PV cell to liquid. "Heat transfer path" in liquid PV-T collectors is basically given by two components of heat exchanger participating in heat transfer: cooling fin system in contact with PV cell/module and thermal bond between piping with heat transfer liquid and cooling fins. Basic scheme has been already illustrated in Figure 1. The heat transfer between inner pipe wall and liquid by forced convection has very limited influence in usual configurations (fin-pipe system, antifreeze mixture).

Figure 5 shows thermal characteristic of "high-tech" PV$\mathrm{T}$ collector with high conductance between PV cell and liquid due to advanced design of heat exchanger in configuration with and without building envelope integration. High-tech collector shows a high specific thermal output at zero difference between the mean liquid temperature and ambient temperature practically in all cases. However, thermal output characteristics differ significantly by heat loss rate at elevated temperature differences between liquid and ambient. The situation is a bit different in the case of "lowtech" PV-T collector (see Figure 6) with bad thermal contact between PV and liquid and simplifications in heat exchanger design to save material and ease production (see Table 2). Characteristics differ significantly in specific thermal output at zero temperature difference while rate of thermal output decrease by heat loss is similar. This is caused by strong impact of heat loss on efficiency factor $F^{\prime}$ of the collector
TABLE 2: Design parameters of considered PV-T collector (hightech, low-tech) characteristics.

\begin{tabular}{lcc}
\hline PV cell parameters & \\
\hline Temperature coefficient & \multicolumn{2}{c}{$\beta=0.45 \% / \mathrm{K}$} \\
Reference efficiency & $\begin{array}{c}\eta_{\mathrm{el}, r}=14.2 \% \\
t_{r}=25^{\circ} \mathrm{C}\end{array}$ \\
Reference temperature & High-tech & Low-tech \\
\hline Heat removal part & $D_{e} / D_{i}=10 / 8 \mathrm{~mm}$ \\
\hline Pipes diameter & $10 \mathrm{~mm}$ & $100 \mathrm{~mm}$ \\
Pipes distance/fin length $W$ & $2 \mathrm{~mm}$ & $0.2 \mathrm{~mm}$ \\
Cooling fin thickness $d$ & $350 \mathrm{~W} / \mathrm{mK}$ & $250 \mathrm{~W} / \mathrm{mK}$ \\
Cooling fin conductivity $\lambda$ & $200 \mathrm{~W} / \mathrm{m} \cdot \mathrm{K}$ & $5 \mathrm{~W} / \mathrm{m} \cdot \mathrm{K}$ \\
Bond conductance $C_{b}$ & \multicolumn{2}{c}{$0.02 \mathrm{~kg} / \mathrm{s} \cdot \mathrm{m}^{2}$} \\
Mass flow rate of liquid & \multicolumn{2}{c}{} \\
\hline
\end{tabular}

TABLE 3: Selected parameters and results for $F^{\prime}$ and temperature difference between PV and liquid.

\begin{tabular}{lcccc}
\hline$W(\mathrm{~mm})$ & $d \times \lambda(\mathrm{W} / \mathrm{K})$ & $C_{b}(\mathrm{~W} / \mathrm{mK})$ & $F^{\prime}(-)$ & $t_{\mathrm{PV}}-t_{m}(\mathrm{~K})$ \\
\hline $\mathbf{1 0}$ & $\mathbf{0 . 7}$ & $\mathbf{2 0 0}$ & $\mathbf{0 . 9 9}$ & $\mathbf{0 . 9}$ \\
80 & 0.7 & 200 & 0.91 & 7.4 \\
160 & 0.7 & 200 & 0.82 & 14.4 \\
100 & 0.1 & 200 & 0.87 & 11.1 \\
100 & 0.01 & 200 & 0.71 & 23.9 \\
100 & 0.002 & 200 & 0.49 & 40.6 \\
100 & 0.7 & 25 & 0.86 & 11.4 \\
100 & 0.7 & 5 & 0.76 & 19.9 \\
100 & 0.7 & 2 & 0.61 & 31.3 \\
$\mathbf{1 0 0}$ & $\mathbf{0 . 0 5}$ & $\mathbf{5}$ & $\mathbf{0 . 6 9}$ & $\mathbf{2 4 . 4}$ \\
\hline
\end{tabular}

(mainly the heat exchanger cooling PV cells in the function of absorber) when $F^{\prime}$ value becomes very low. Therefore, building envelope integration of low-tech PV-T collector significantly increases the effectiveness of heat removal from PV even for very small liquid temperature difference from ambient compared to high-tech PV-T collector. In other words, while building integration brings negligible effect to high-tech PV-T collector for low operation temperatures, it brings a large improvement to low-tech PV-T collectors.

Relationship between the PV-liquid temperature difference and efficiency factor $F^{\prime}$ for BIPV-T collectors has been shown in Figure 7. The relationship has approximately a linear character. Low values of efficiency factor $F^{\prime}$ are generally caused by low conductance of the bond between risers and cooling fin/plate, low fin thermal conductivity and thickness product or large length of cooling fin. Individual points in Figure 7 represent practically possible values of the parameters or their combinations in usual range (bond conductance from 2 to $200 \mathrm{~W} / \mathrm{mK}$, conductivity-thickness product from 0.002 to $0.07 \mathrm{~W} / \mathrm{K}$, and cooling fin length from 10 to $200 \mathrm{~mm}$ ). For given boundary conditions, efficiency factor values have been highlighted for investigated building integrated high-tech and low-tech PV-T configurations. Because of poor heat transfer between PV cell and heat removal liquid in the low-tech BIPV-T collector, the large 


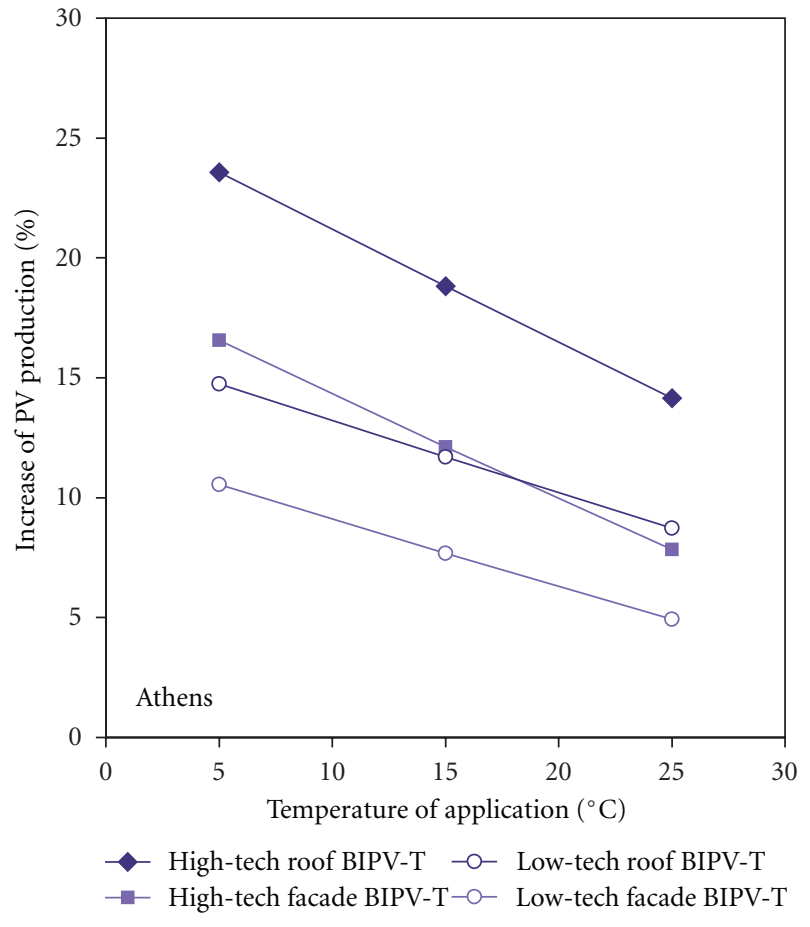

(a)

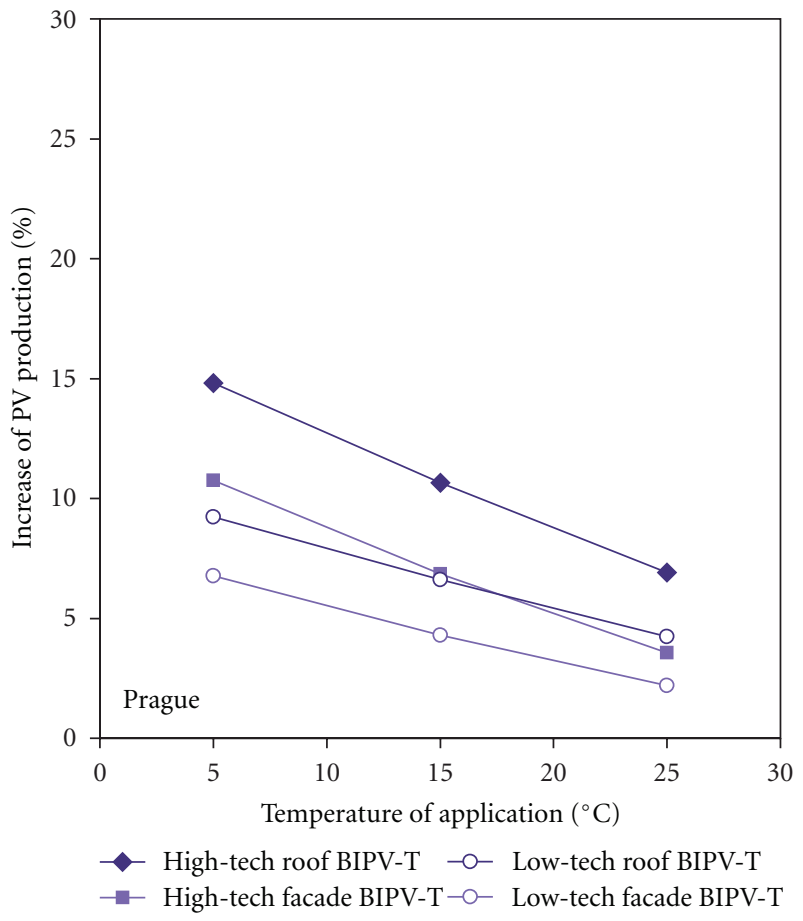

(b)

FIGURE 10: Increase of electricity production from BIPV modules by use of BIPV-T collectors.

temperature difference between PV cell and liquid is established. The question is how it could affect the ability of such configuration to sufficiently cool the PV cells and avoid overheating in real operation for a given climate.

Table 3 shows the selected points from graph in Figure 7 representing different geometry and physical parameters of PV-T collector configurations. Rows for investigated low-tech and high-tech PV-T collector configurations are highlighted.

\section{Combined Heat and Electricity Production}

Energy (electricity, heat) production for two unglazed BIPV$T$ collectors with different heat removal quality has been simulated. Mathematical models of BIPV-T collectors discussed above have been used to investigate whole year performance in two different climates (Athens, Prague) and for three temperature levels representing the typical applications of low potential heat utilization: primary circuits of heat pumps $\left(5^{\circ} \mathrm{C}\right)$, cold water preheating $\left(15^{\circ} \mathrm{C}\right)$, and pool water preheating $\left(25^{\circ} \mathrm{C}\right)$. The temperatures were considered as temperatures of liquid entering the PV-T collector and were kept constant throughout the year in time periods when cooling of PV could bring a heat gain.

Figures 8 and 9 show the results for warm and moderate climate conditions. It is apparent that heat production is up to ten times higher than electricity production from BIPV-T collectors. Part of the thermal output is a heat gain from ambient environment especially for applications with low operation temperatures. Low-tech BIPV-T collector achieves only around $65 \%$ of high-tech thermal output regardless of application temperature and climate. Electricity production from low-tech and high-tech BIPV-T collectors differs in range of several percents for applications with higher temperatures $\left(25^{\circ} \mathrm{C}\right)$ and up to $7 \%$ for applications with very low temperatures $\left(5^{\circ} \mathrm{C}\right)$.

Improvement in electricity production by use of BIPV$\mathrm{T}$ collectors instead of BIPV modules without cooling has been shown in Figure 10 for warm climate (a) and moderate climate (b). High-tech BIPV-T collectors show high improvement in electric performance up to $25 \%$ in annual electric yield for warm climate and $15 \%$ for moderate climate for roof installations while relevant figures for lowtech BIPV-T are $15 \%$ and $9 \%$. Despite that the low-tech BIPV-T collectors achieve lower improvement in electric yields when compared with ideal high-tech configuration, the figures are still encouraging for their application due to low production costs. Facade BIPV-T collectors show generally lower improvement in electric performance than roof installations, relatively about 30 to $50 \%$ when compared to roof percent figures (see Figure 10).

\section{Conclusions}

Drawbacks associated with integration of PV modules into building envelopes (roofs, facades) have been outlined. Reduction of electricity production above $5 \%$ has been shown both for warm and moderate climate compared to separate installation. Moreover, extreme temperatures of PV cells leading to degradation problems could appear at 
considerable frequency for roof BIPV especially in warm climate, but temperatures above $80^{\circ} \mathrm{C}$ are present even in the moderate climate. Facade integration doesn't show real problems to safe operation of PV for considered climates.

Knowledge of the BIPV figures results in application of PV-T collectors for installations with high degree of integration into building construction (facade or roof claddings). Expensive high-tech and low cost low-tech configurations have been discussed to reveal differences in thermal performance of both as an indicator of overall PV$\mathrm{T}$ performance. Main factors defining the quality of PV-T thermal performance are cooling fin quality (conductivity, thickness, and length) and bond conductance between riser pipe and cooling fin. Building integration brings a large improvement especially to low-tech PV-T collectors. While high-tech BIPV-T collector configuration shows negligible temperature difference between PV and liquid at nominal conditions (efficiency factor $F^{\prime}=0.99$ ), low-tech BIPV-T configuration results in large temperature difference around $25 \mathrm{~K}$ due to worse heat removal from PV cell $\left(F^{\prime}=0.69\right)$.

A simulation study has been performed for these two configurations to show the potential energy production in different climates and applications. There is a huge potential for roof applications of BIPV-T collectors instead of BIPV with $15 \%$ to $25 \%$ increase of electricity production in warm climate (Athens) and $8 \%$ to $15 \%$ increase in moderate climate (Prague). Associated heat production is from several times to 10 times higher than electricity production. High values are valid for low application temperatures $\left(5^{\circ} \mathrm{C}\right)$ where a large portion of ambient heat is also used. Low-tech BIPV$\mathrm{T}$ collectors could contribute with reduced performance level but still with considerable improvement when compared to BIPV modules without cooling.

\section{References}

[1] T. Matuska, "Advanced solar collectors for building integration," in Proceedings of the World Renewable Energy Congress (WREC-X), pp. 1547-1552, Glasgow, UK, 2008.

[2] P. G. Charalambous, G. G. Maidment, S. A. Kalogirou, and K. Yiakoumetti, "Photovoltaic thermal (PV/T) collectors: a review," Applied Thermal Engineering, vol. 27, no. 2-3, pp. 275286, 2007.

[3] H. A. Zondag, "Flat-plate PV-Thermal collectors and systems: a review," Renewable and Sustainable Energy Reviews, vol. 12, no. 4, pp. 891-959, 2008.

[4] T. T. Chow, "A review on photovoltaic/thermal hybrid solar technology," Applied Energy, vol. 87, no. 2, pp. 365-379, 2010.

[5] A. Ibrahim, M. Y. Othman, M. H. Ruslan, S. Mat, and K. Sopian, "Recent advances in flat plate photovoltaic/thermal (PV/T) solar collectors," Renewable and Sustainable Energy Reviews, vol. 15, no. 1, pp. 352-365, 2011.

[6] Y. Tripanagnostopoulos, "Aspects and improvements of hybrid photovoltaic/thermal solar energy systems," Solar Energy, vol. 81, no. 9, pp. 1117-1131, 2007.

[7] M. Bakker, H. A. Zondag, M. J. Elswijk, K. J. Strootman, and M. J. M. Jong, "Performance and costs of a roof-sized $\mathrm{PV} /$ thermal array combined with a ground coupled heat pump," Solar Energy, vol. 78, no. 2, pp. 331-339, 2005.
[8] E. Bertram, M. Stegmann, J. Scheuren, C. Rosinski, and K. Kundmüller, "Unglazed photovoltaic thermal collectors in heat pump systems," in Proceedings of the Eurosun 2010, Graz, Austria, 2010.

[9] G. Fraisse, C. Ménézo, and K. Johannes, "Energy performance of water hybrid PV/T collectors applied to combisystems of direct solar floor type," Solar Energy, vol. 81, no. 11, pp. 14261438, 2007.

[10] P. Dupeyrat, C. Ménézo, M. Rommel, and H. M. Henning, "Efficient single glazed flat plate photovoltaic-thermal hybrid collector for domestic hot water system," Solar Energy, vol. 85, no. 7, pp. 1457-1468, 2011.

[11] H. A. Zondag, D. W. de Vries, W. G. J. van Helden, R. J. C. van Zolingen, and A. A. van Steenhoven, "The yield of different combined PV-thermal collector designs," Solar Energy, vol. 74, no. 3, pp. 253-269, 2003.

[12] T. T. Chow, J. W. Hand, and P. A. Strachan, "Buildingintegrated photovoltaic and thermal applications in a subtropical hotel building," Applied Thermal Engineering, vol. 23, no. 16, pp. 2035-2049, 2003.

[13] T. T. Chow, W. He, and J. Ji, "An experimental study of façade-integrated photovoltaic/water-heating system," Applied Thermal Engineering, vol. 27, no. 1, pp. 37-45, 2007.

[14] T. N. Anderson, M. Duke, G. L. Morrison, and J. K. Carson, "Performance of a building integrated photovoltaic/thermal (BIPVT) solar collector," Solar Energy, vol. 83, no. 4, pp. 445455, 2009.

[15] T. Bergene and O. M. Løvvik, "Model calculations on a flatplate solar heat collector with integrated solar cells," Solar Energy, vol. 55, no. 6, pp. 453-462, 1995.

[16] H. A. Zondag, D. W. de Vries, W. G. J. van Helden, R. J. C. van Zolingen, and A. A. van Steenhoven, "The thermal and electrical yield of a PV-thermal collector," Solar Energy, vol. 72, no. 2, pp. 113-128, 2002.

[17] T. T. Chow, "Performance analysis of photovoltaic-thermal collector by explicit dynamic model," Solar Energy, vol. 75, no. 2, pp. 143-152, 2003.

[18] T. Matuska, "Theoretical analysis of solar unglazed hybrid photovoltaic-thermal liquid collector," in Proceedings of the Eurosun 2010, Graz, Austria, 2010.

[19] T. Matuska and L. Buchta, "Experimental investigation of solar PV-T/liquid collector," in Proceedings of the ISES Solar World Congress 2011, Kassel, Germany, 2011.

[20] H. C. Hottel and A. Whillier, "Evaluation of flat-plate solar collector performance," in Transactions of the Conference on Use of Solar Energy, vol. 2, pp. 74-78, University of Arizona Press, 1958.

[21] L. W. Florschuetz, "Extension of the Hottel-Whillier model to the analysis of combined photovoltaic/thermal flat plate collectors," Solar Energy, vol. 22, no. 4, pp. 361-366, 1979.

[22] “Climate databases from Meteonorm 5.1,” Meteotest, 2004. 


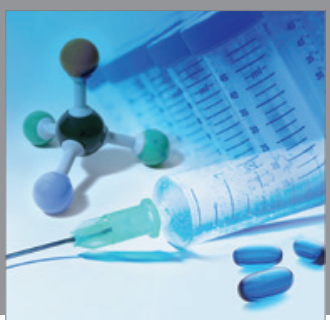

International Journal of

Medicinal Chemistry

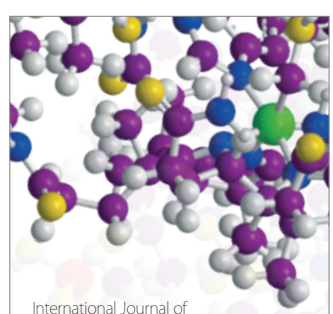

Carbohydrate Chemistry

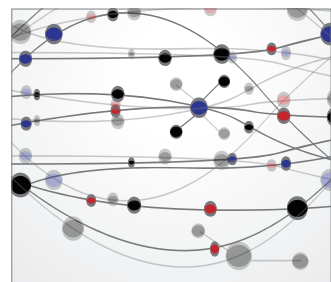

The Scientific World Journal
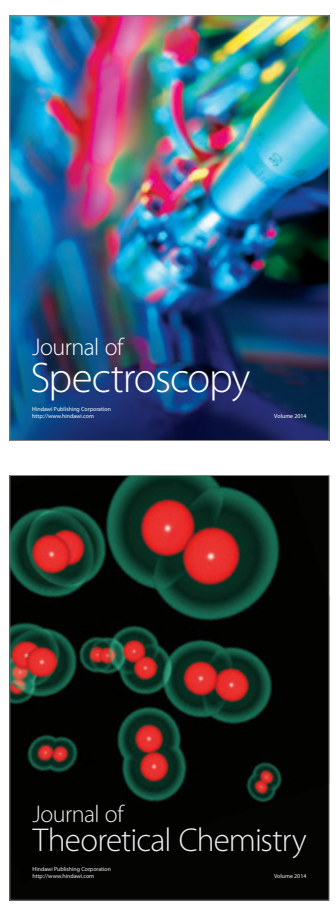
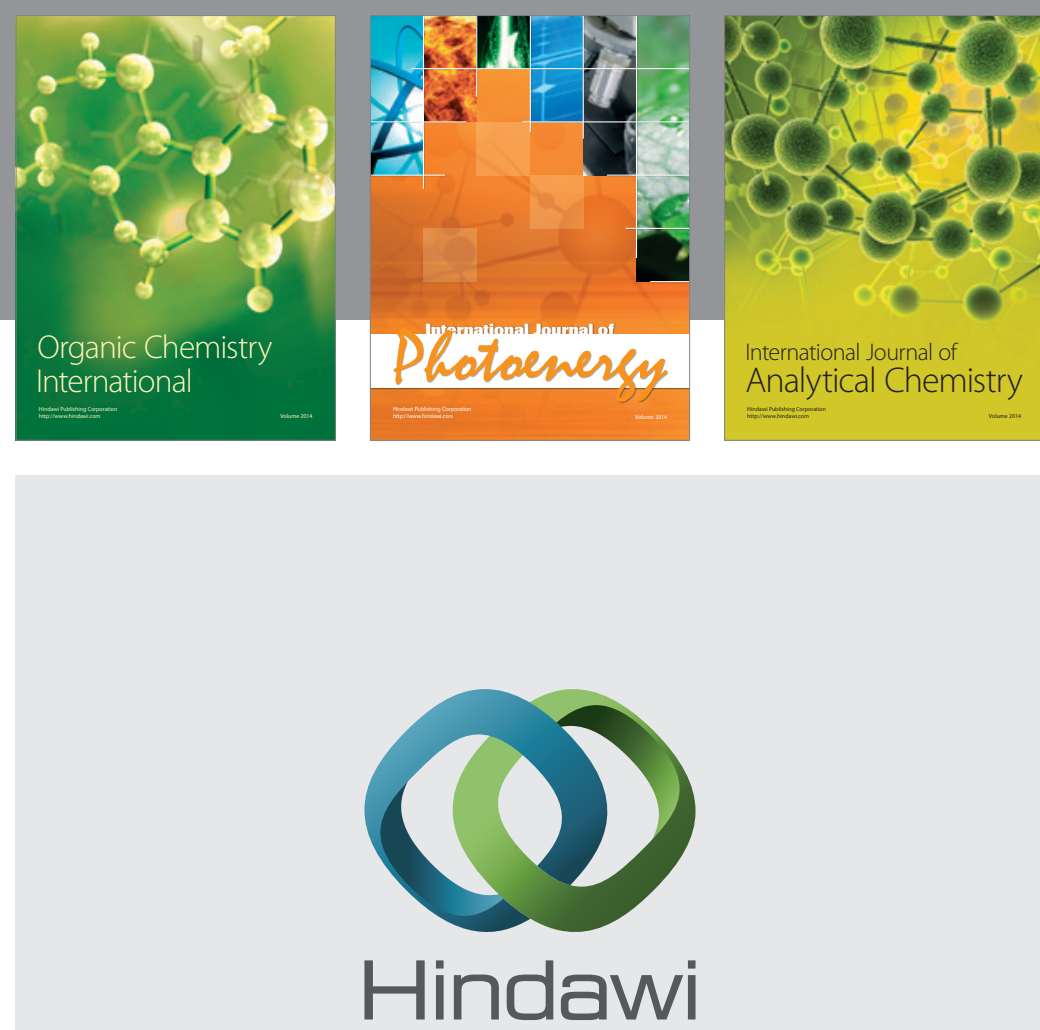

Submit your manuscripts at

http://www.hindawi.com
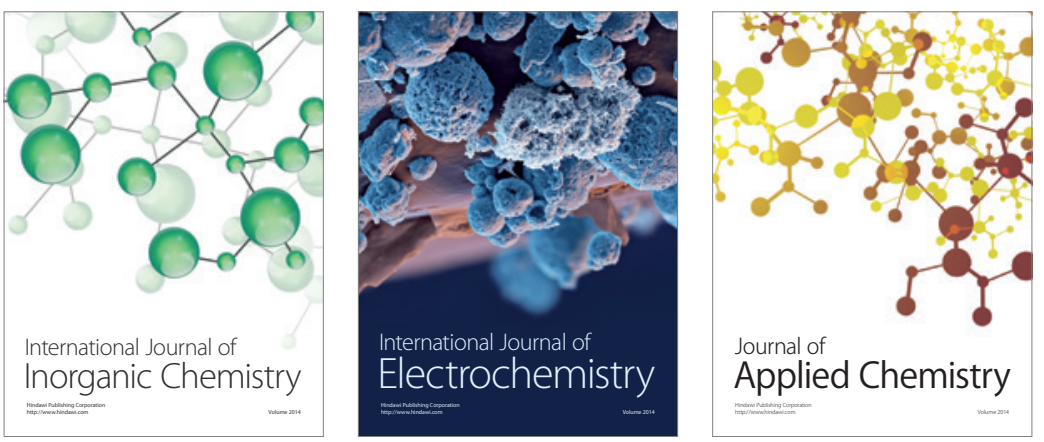

Journal of

Applied Chemistry
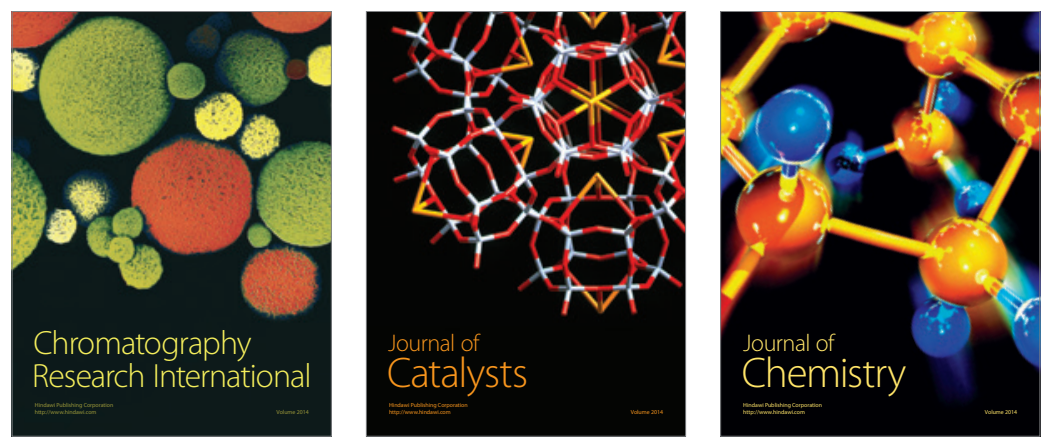
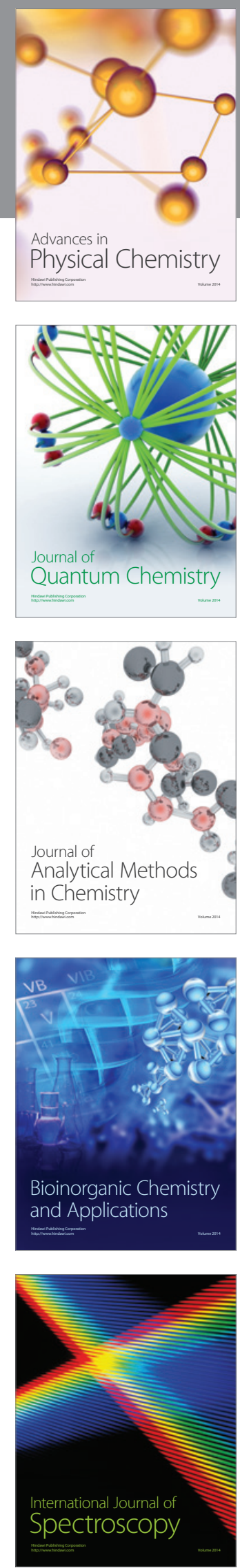